\title{
PEMISAHAN SENYAWA-SENYAWA YANG BERSIFAT SITOTOKSIK TERHADAP SEL MURIN LEUKEMIA P388 DARI EKSTRAK METANOL KULIT BATANG DIPTEROCARPUS CONFERTUS SLOOT (DIPTEROCARPACEAE)
}

\author{
Muhtadi dan Peni Indrayudha \\ Fakultas Farmasi, Universitas Muhammadiyah Surakarta \\ Correspondence to: Muhtadi \\ Email: muhtadi@ums.ac.id
}

\begin{abstract}
Six compounds, KP-1 up to KP-6 were isolated from the methanol extract of the tree bark of Dipterocarpus confertus Sloot (Dipterocarpaceae). The cytotoxic activities of these compounds were evaluated against murine leukemia P388 cells. Result of these examination indicated that KP-2 compound and KP-1 were very active with each $I C_{50}$ value of these compounds were 2.25 and $5.1 \mu \mathrm{g} / \mathrm{mL}$, respectively. While the others were not active against murine leukemia P388 cells.
\end{abstract}

Keywords: Dipterocarpaceae, Dipterocarpus confertus Sloot, isolated compounds, cytotoxic, and murine leukemia P-388 cell

\section{PENDAHULUA N}

Dipterocarpaceae atau yang lebih dikenal dengan nama daerah "meranti, keruing, atau kamfer" merupakan salah satu famili tumbuhan yang relatif besar yang terdiri dari 16 genus dan 600 spesies (Cronquist, 1981). Keberadaan tumbuhan ini sangat melimpah di wilayah Indonesia tengah khususnya di pulau Kalimantan dan Sumatera dan penyebarannya meliputi Indonesia bagian barat, Malaysia, Brunei dan Filipina, serta ke arah timur hingga Irian Jaya dan Papua Niugini (Newman et al., 1999). Tiga genus utama dari famili ini adalah Shorea ("meranti", 150 spesies), Hopea ("merawan" atau "tengkawang" atau "damar mata kucing", 100 spesies) dan Dipterocarpus ("keruing", 75 spesies) (Newman et al., 1999; Soerianegara dan Lemmens, 1994).

Dipterocarpaceae merupakan tumbuhan penghasil kayu yang sangat unggul kualitasnya, karena memiliki batang lurus, berpenampang bundar, hanya sedikit sekali yang bercabang, memiliki kayu yang berat, keras, berserat kasar, dan kuat dengan diameter melintang diatas $50 \mathrm{~cm}$, sehingga sangat baik untuk bahan bangunan dan industri kayu lapis (Sukhla et al., 1990). Kayu meranti dan keruing misalnya, adalah jenis kayu bangunan yang berkualitas tinggi karena tahan rayap atau serangga lainnya. Disamping itu, tumbuhan Dipterocarpaceae juga penghasil resin atau damar yang tinggi, yang digunakan untuk varnish atau cat. Sementara itu, biji tengkawang yang dihasilkan dari tumbuhan Shorea dan Isoptera, dapat digunakan untuk berbagai keperluan seperti bahan industri makanan, sabun, obat-obatan seperti obat sariawan dan kosmetika. Oleh karena itu, tumbuhan ini merupakan sumber devisa negara yang sangat potensial untuk komoditi ekspor (Heyne, 1987).

Berdasarkan penelusuran literatur, kandungan metabolit sekunder dari tumbuhan famili Dipterocarpaceae sangat beraneka ragam, yang meliputi golongan fenol, seperti oligostilbenoid (oligomer resveratrol), flavonoid, fenilpropanoid, dan turunan asam fenolat, serta golongan non-fenol, yaitu triterpenoid (Hegnauer, 1966; Sotheeswaran and Pasuphaty, 1993; Hakim, 2002).

Senyawa-senyawa oligomer resveratrol yang diperoleh dari hasil isolasi tumbuhan famili Dipterocarpaceae mempunyai aktivitas biologi yang potensial pada beberapa uji farmakologi, seperti anti-HIV (Dai et al., 1998), antibakteri 
(Sultanbawa et al., 1987; Geewananda et al., 1986; Zgoda-Pols et al., 2002), antifungal (Pryce and Langcake, 1977; Bokel et al., 1988), antioksidan (Tanaka et al., 2000-b), antiinflamasi (Kitanaka et al., 1990; Huang, 2001), sitotoksik (Dai et al., 1998; Ito et al., 2001-b) dan hepatoprotektif (Oshima et al., 1993). Selain itu, beberapa senyawa oligomer resveratrol juga dilaporkan dapat menghambat enzim 5a-reduktase (Hirano et al., 2001) dan enzim asetilkolinesterase (Sung et al., 2002).

$$
\text { Genus Dipterocarpus yang }
$$

merupakan genus terbesar ketiga dalam famili Dipterocarpaceae, ternyata belum banyak dikaji aspek kandungan metabolit sekundernya khususnya dari golongan senyawa fenolik. Berdasarkan kajian literatur dari 75 spesies yang ada di dunia, 38 spesies diantaranya ada di Indonesia dan ternyata baru 5 (lima) spesies dari genus ini yang telah diteliti kandungan metabolit sekundernya. Satu spesies, D. grandiflorus diteliti oleh Ito et al. (2004) diperoleh empatbelas senyawa fenolik, dua diantaranya adalah senyawa baru yaitu grandifenol A dan B. Empat spesies yang lain, D. retusus Blume, D. hasseltii Blume, $D$. intricatus Dyer dan D. elongatus Korth telah dikerjakan oleh peneliti dalam kurun waktu 3 (tiga) tahun terakhir (Muhtadi, 2005; 2006a; 2006b; 2006c; 2006d, 2007).

Fakta fitokimia dari genus ini memperkuat informasi ilmiah sebelumnya, bahwa tumbuhan famili Dipterocarpaceae, memiliki kandungan utama senyawa-senyawa oligomer resveratrol yang memiliki efek farmakologis yang potensial dan menarik. Senyawa (-)-vatikanol C yang diisolasi dari dua spesies Dipterocarpus, yakni dari $D$. intricatus dan $D$. grandiflorus telah dilaporkan memiliki aktivitas antikanker yang tinggi terhadap sepuluh sel panel kanker yang diujikan, sehingga telah dipromosikan sebagai obat antikanker oleh Ito et al. (2001-b). Adanya kecenderungan diperolehnya senyawa-senyawa tetramer resveratrol yang baru dari genus Dipterocarpus, memberikan peluang diperolehnya bahan obat alam yang baru dan berpotensi dalam aktivitasnya sebagai antikanker.

Dalam makalah ini akan disampaikan pemisahan enam senyawa KP-1 hingga KP-6 dari ekstrak metanol kulit batang tumbuhan D. confertus Sloot dan aktivitas sitotoksiknya terhadap sel murin leukemia P-388. Pemisahan senyawa-senyawa fenolik dari spesies $D$. confertus Sloot ini merupakan penelitian terbaru yang belum pernah dilaporkan sebelumnya.

Karakterisasi senyawa-senyawa hasil-hasil isolasi ditetapkan berdasarkan data spektroskopi $\mathrm{UV}, \mathrm{IR},{ }^{1} \mathrm{H}-\mathrm{NMR}$ dan ${ }^{13} \mathrm{C}-\mathrm{NMR}$ serta perbandingan dengan data sejenis yang telah dilaporkan. Sedangkan uji sitotoksisitasnya ditentukan dengan menggunakan sel murin leukemia P-388 berdasarkan prosedur standar NCI (Hostettmann, 1991).

\section{METODE PENELITIAN}

Alat. Spektrum UV dan IR ditetapkan dengan Cary Varian 100 Conc. dan PerkinElmer Spectrum One FT-IR spectrophotometers. Spektrum ${ }^{1} \mathrm{H}$ dan ${ }^{13} \mathrm{C}-\mathrm{NMR}$ ditentukan dengan spektrofotometer JEOL ECP400, yang beroperasi pada $400 \mathrm{MHz}\left({ }^{1} \mathrm{H}\right)$ dan $100 \mathrm{MHz}\left({ }^{13} \mathrm{C}\right)$. Kromatografi cair vakum menggunakan Silika 60 $\mathrm{GF}_{254}$ (Merck), kromatografi radial menggunakan Silika $60 \mathrm{PF}_{254}$ (Merck), dan analisis KLT menggunakan plat KLT Kieselgel $60 \mathrm{GF}_{254} 0,25$ mm (Merck).

Bahan. Bahan tumbuhan yang digunakan adalah kulit batang D. confertus Sloot, diperoleh dari Bukit Bengkirai Kalimantan Timur (Kaltim), pada bulan Oktober 2005. Tumbuhan tersebut telah diidentifikasi oleh staf Herbarium Bogoriensis dan spesimennya telah disimpan di laboratorium Herbarium Bogoriensis, Lembaga Ilmu Pengetahuan Indonesia (LIPI) Bogor. Sedangkan pelarut yang digunakan semuanya berkualitas teknis yang telah didestilasi.

\section{Ekstraksi dan isolasi}

Serbuk kering kulit batang $D$. confertus Sloot sebanyak 4,3 kg diekstraksi dengan metanol $(10 \mathrm{~L})$ menggunakan teknik maserasi tiga kali berturut-turut@24 jam menghasilkan4480 g ekstrak metanol total. Ekstrak metanol tersebut, selanjutnya dilarutkan kembali dalam campuran $\mathrm{MeOH}$-dietileter untuk pengendapan taninnya, sehingga menghasilkan fraksi terlarut $\mathrm{MeOH}-$ dietileter, berupa gum berwarna coklat gelap (284 g). Fraksi MeOH-dietileter sebanyak $50 \mathrm{~g}$ kemudian difraksinasi dengan kromatografi cair vakum (KCV) dalam 2 kali pengerjaan [adsorben Si-gel, eluen yang digunakan heksan-etilasetat (6:4-etilasetat $100 \%$, etilasetat : metanol (76:3)] menghasilkan 9 fraksi utama A s.d I (masing- 
masing tidak ditimbang (A); 0,$30 ; 0,50 ; 1,40 ; 3,22$; 0,$40 ; 0,367 ; 2,0$ dan 4,84 g). Fraksi C (berat 500 $\mathrm{mg}$ ) dilakukan pemurnian terlebih dahulu, dengan metode kromatografi kolom tekan (KKT) diameter kolom $4 \mathrm{~cm}$ dan eluen yang digunakan $\mathrm{n}$-heksana : etilasetat $=8: 2$. Setelah dilanjutkan dengan proses rekristalisasi diperoleh senyawa KP-2 (berat $113 \mathrm{mg}$ ). Sedangkan dari proses pemurnian dari fraksi $\mathrm{C}_{2}$, dengan cara rekristalisasi dan pencucian dengan pelarut metanol, diperoleh senyawa KP-3 (sebanyak $105 \mathrm{mg}$ ). Dari fraksi gabungan $\mathrm{E}$ dan $\mathrm{F}$, dilakukan rekristalisasi dan pencucian dengan pelarut aseton dan metanol diperoleh senyawa KP-1 (sebanyak 190 mg). Dari fraksi H sebanyak $670 \mathrm{mg}$ dilakukan pemurnian dengan metode KKT berulang-ulang, diperoleh senyawa KP-4 sebanyak $210 \mathrm{mg}$ dan KP-6 sebanyak 5 mg. Sedangkan dari fraksi G (sebanyak $350 \mathrm{mg}$ ) dilakukan pemurnian dengan metode KKT dua tahap, diperoleh senyawa KP-5 (berat $23 \mathrm{mg}$ ).

\section{Pengujian aktivitas sitotoksik}

Aktivitas sitotoksik senyawa KP-1 s.d KP-5 dinyatakan sebagai $\mathrm{IC}_{50}$, yaitu konsentrasi sampel yang dibutuhkan untuk menginhibisi $50 \%$ sel murin leukemia P-388 melalui pewarnaan pereaksi MTT. Uji dilakukan dengan cara menambahkan berbagai konsentrasi ketiga senyawa tersebut ke dalam biakan sel murin leukemia P-388. Setelah diinkubasi selama 48 jam, ke dalam sampel ditambahkan pereaksi warna MTT dan diinkubasikan kembali selama 4 jam. Jumlah sel tumor P-388 yang terinhibisi oleh sampel diukur dari serapannya dengan menggunakan alat pembaca pelat mikro pada $\lambda 540 \mathrm{~nm}$ setelah penambahan larutan penghenti pertumbuhan. Nilai IC $_{50}$ dapat dihitung melalui ekstrapolasi garis $50 \%$ serapan kontrol positif pada kurva serapan terhadap berbagai konsentrasi sampel menggunakan grafik semilogaritma.

\section{HASIL DAN PEMBAHASAN}

Enam senyawa murni telah berhasil diisolasi dari kulit batang D. confertus Sloot. Berdasarkan analisis data spektroskopi yang sudah ada, menunjukkan bahwa KP-1 dan KP-3 mengindikasikan sebagai senyawa triterpenoid, senyawa KP-2, KP-5 dan KP-6 mengindikasikan sebagai flavonoid, sedangkan senyawa KP-4 adalah trimer resveratrol, yaitu $\alpha$-viniferin.

Senyawa KP-1, diperoleh sebagai serbuk putih, spektrum UV (MeOH) $\lambda_{\text {maks }} 203,5 \mathrm{~nm}$, khas untuk kromofor senyawa nonfenolik; sedangkan spektrum IR (pellet KBr) menunjukkan puncakpuncak serapan pada $v_{\text {maks }} 2943$ dan $2869 \mathrm{~cm}^{-1}$ (C-H alifatik), $1687 \mathrm{~cm}^{-1}$ (C=C alifatik), 1234 dan $1191 \mathrm{~cm}^{-1}$ (C-OH alifatik), memperkuat sebagai senyawa nonfenolik. Pengukuran H-NMR dan C-NMR sedang dikerjakan (di UKM). Berdasarkan data spektrum UV dan IR, senyawa KP-1 mengindikasikan sebagai senyawa triterpenoid.

Senyawa KP-2, diperoleh sebagai serbuk kuning, spektrum UV (MeOH) $\lambda_{\text {maks }} 205,229,5$ dan 329,5 nm. Penambahan $\mathrm{NaOH}$ terjadi pergeseran batokromik sebesar $9 \mathrm{~nm}$ pada pita I. IR (KBr) $\quad v_{\text {maks }} 3026 \mathrm{~cm}^{-1}(-\mathrm{OH}), 1651,1573$, dan $1448 \mathrm{~cm}^{-1}(\mathrm{C}=\mathrm{C}$ benzena), 1342 dan 1193 $\mathrm{cm}^{-1}$ (C-O oksiaril). Pengukuran H-NMR dan C-NMR sedang diproses (di UKM). Berdasarkan data spektrum UV dan IR, senyawa KP-2 mengindikasikan sebagai senyawa flavonoid.

Senyawa KP-3, diperoleh sebagai serbuk putih, spektrum UV (MeOH) $\lambda_{\text {maks }} \quad 202,5$ $\mathrm{nm}$; spektrum IR senyawa senyawa KP-3 menunjukkan adanya serapan yang kuat pada bilangan gelombang $v_{\text {maks }} 3204 \mathrm{~cm}^{-1}$ yang berasal dari regangan ulur gugus $\mathrm{O}-\mathrm{H}$, diikuti dengan serapan pada bilangan gelombang $v_{\text {maks }} 1049 \mathrm{~cm}^{-1}$ dari gugus $\mathrm{C}-\mathrm{O}$ alkohol sekunder. Pada bilangan gelombang $v_{\text {maks }} 2900$ dan $2850 \mathrm{~cm}^{-1}$ terdapat serapan yang sangat kuat dari regangan ulur gugus $\mathrm{C}-\mathrm{H}$ alifatik gugus $\mathrm{CH}_{2}$ dan $\mathrm{CH}_{3}$ diikuti dengan serapan pada $v_{\text {maks }} 1464$ dan $1379 \mathrm{~cm}^{-1}$ yang berasal dari tekukan $\mathrm{C}-\mathrm{H}$ alifatik dari gugus $\mathrm{CH}_{2}$ dan $\mathrm{CH}_{3}$ yang khas untuk golongan terpenoid. Adanya serapan dengan intensitas lemah pada bilangan gelombang $v_{\text {maks }} 1622 \mathrm{~cm}^{-1}$ menunjukkan adanya regangan ulur $\mathrm{C}=\mathrm{C}$ dari gugus $\mathrm{C}-\mathrm{H}$ rangkap dua $(-\mathrm{C}=\mathrm{C}-\mathrm{H})$ siklik. Berdasarkan analisis database IR-nya, memiliki kemiripan dengan $\beta$-sitosterol sebesar $93 \%$. Sehingga dapat disimpulkan bahwa senyawa KP-3 adalah senyawa $\beta$-sitosterol.

Senyawa KP-4, diperoleh sebagai serbuk putih kecoklatan, spektrum UV (MeOH) $\lambda_{\text {maks }}$ 213,5, 228 (bahu) dan $286 \mathrm{~nm}$. Penambahan $\mathrm{NaOH}$ terjadi pergeseran batokromik sebesar $11 \mathrm{~nm}$, yang khas untuk kromofor stilben (Ito et al., 2001-a). Spektrum IR (pellet KBr) senyawa KP-4 memperlihatkan ciri-ciri yang sesuai untuk senyawa oligomer resveratrol dengan pita-pita serapan pada $v_{\text {maks }} 3355 \mathrm{~cm}^{-1}(-\mathrm{OH})$, 
1614, 1515, dan $1446 \mathrm{~cm}^{-1} \quad(\mathrm{C}=\mathrm{C}$ benzena $)$, 1361 dan $1170 \mathrm{~cm}^{-1}$ (C-O oksiaril) serta dan $831 \mathrm{~cm}^{-1}$ ( $p$-disubstitusibenzena). Berdasarkan data spektrum UV dan IR, senyawa KP-4 mengindikasikan sebagai senyawa oligomer resveratrol dengan ikatan rangkap yang telah

tersubstitusi.
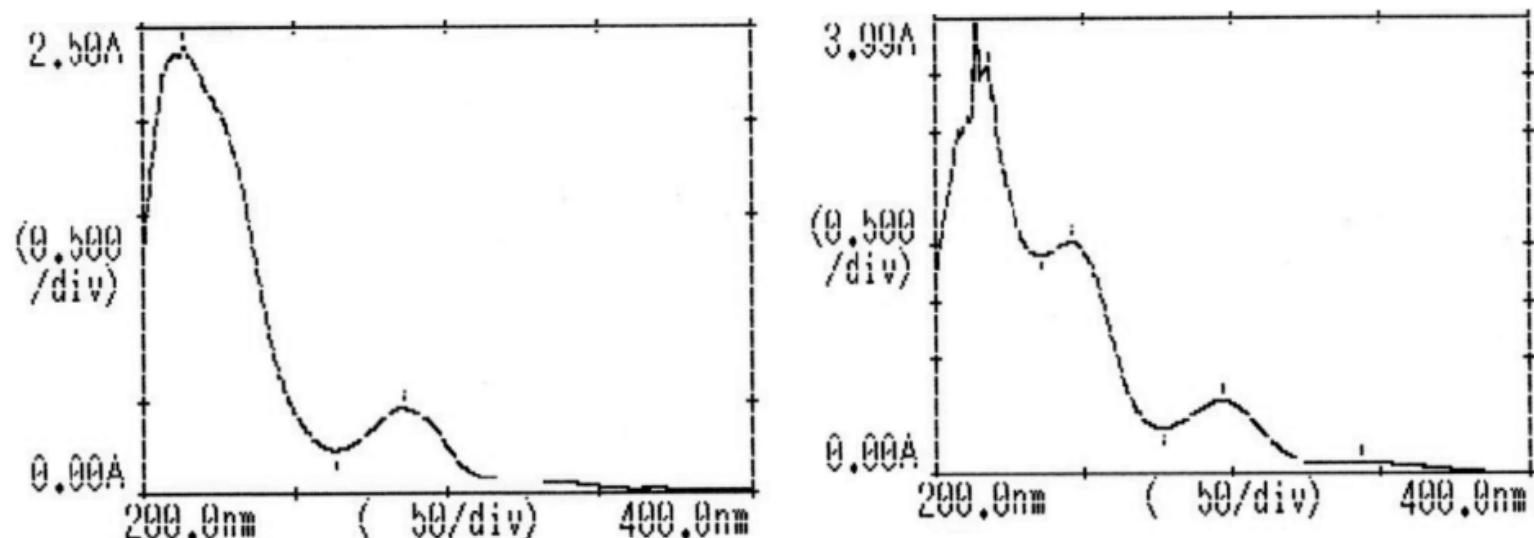

Gambar 1. Spektrum UV KP-4 (MeOH) (kiri) dan KP-4 + NaOH (kanan)

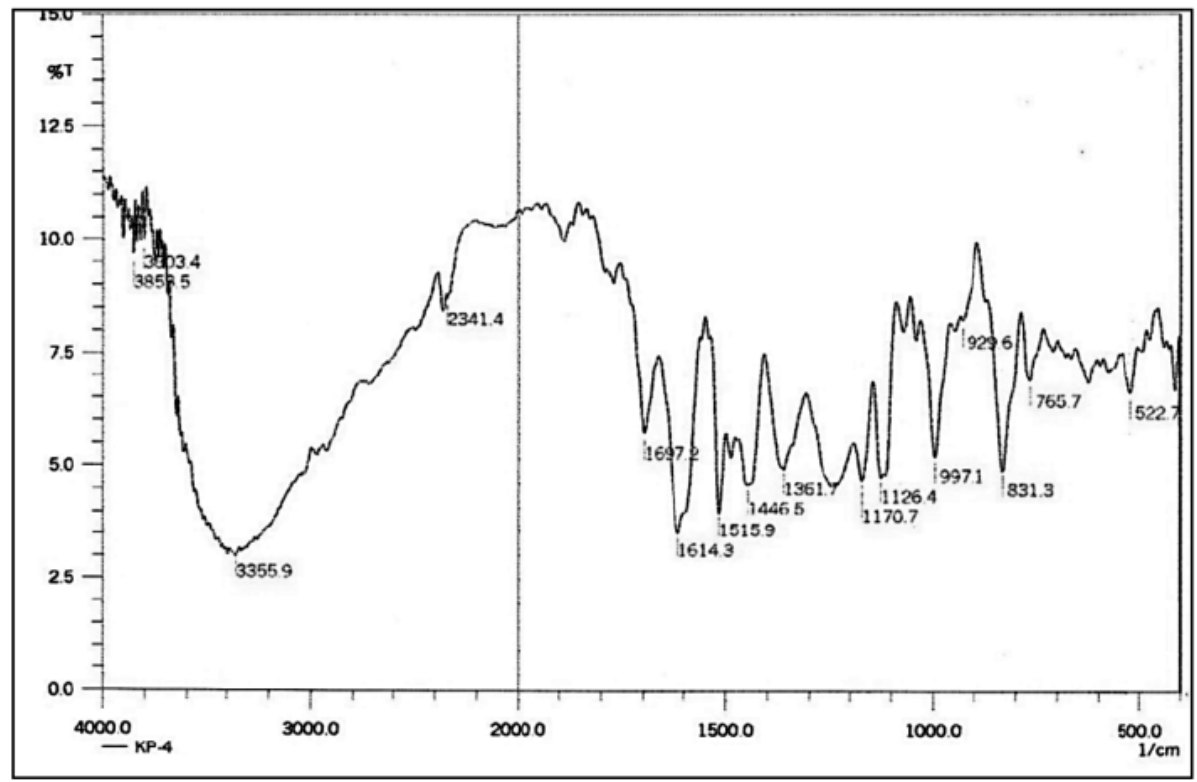

Gambar 2. Spektrum IR KP-4 (pellet KBr)

Data spektrum ${ }^{13} \mathrm{C}$ NMR (Tabel 1) menunjukkan adanya 35 sinyal yang mewakili 42 karbon, mengindikasikan bahwa senyawa KP-4 adalah suatu trimer resveratrol ( 3 X 14 karbon). Sinyal-sinyal karbon yang menjadi karakteristik dari senyawa KP-4 adalah adanya enam karbon alifatik pada $\delta_{C} 46,4-95,6 \mathrm{ppm}$, yang menunjukkan adanya tiga cincin dihidrobenzofuran, sembilan karbon kuarterner $\left(\delta_{\mathrm{C}} 118,8-141,2 \mathrm{ppm}\right)$; yang meliputi enam karbon kuarterner merupakan bagian dari kerangka dasar karbon siklononan dan tiga karbon kuarterner $\left(\delta_{\mathrm{C}} 130,0-132,2 \mathrm{ppm}\right)$ untuk C-1a/b/c; sembilan karbon oksiaril $\left(\delta_{\mathrm{C}} 157,9\right.$ - 161,8 ppm) yang mendukung sebagai trimer resveratrol, dan 18 karbon metin aromatik $\left(\delta_{\mathrm{C}} 96,9\right.$ - 128,7 ppm). Sementara itu, spektrum ${ }^{1} \mathrm{H}$ NMR (Tabel 1) menunjukkan sinyal-sinyal proton yang sesuai untuk tiga unit $p$-hidroksifenil pada $\delta 7,03$; 6,$72 ; 7,02 ; 6,78 ; 7,20$ dan $6,76 \mathrm{ppm}$, adanya tiga unit 1,2,3,5-tetrasubstitusibenzena pada $\delta 6,24 ; 6,72 ; 6,23 ; 5,98 ; 6,20$ dan 6,58 ppm, dan tiga unit 2,3-disubstitusi-2,3-dihidrobenzofuran pada $\delta 6,21 ; 3,95 ; 4,89 ; 4,60 ; 5,93$ dan 4,68 ppm. 
Karakteristik unit-unit struktur tersebut menyarankan bahwa senyawa KP-4 ini memiliki struktur molekul sama dengan (-)- $\alpha$-viniferin yang telah dilaporkan oleh Pryce and Langcake (1977) yang diisolasi dari Vitis vinifera (Vitaceae). Perbandingan data ${ }^{1} \mathrm{H}$ dan ${ }^{13} \mathrm{C}$ NMR (Tabel 1) senyawa KP-4 dengan (-)- $\alpha$-viniferin oleh Pryce and Langcake (1977) memperlihatkan kesesuaian yang tinggi. Dengan demikian dapat disimpulkan bahwa senyawa KP-4 adalah $\alpha$-viniferin.

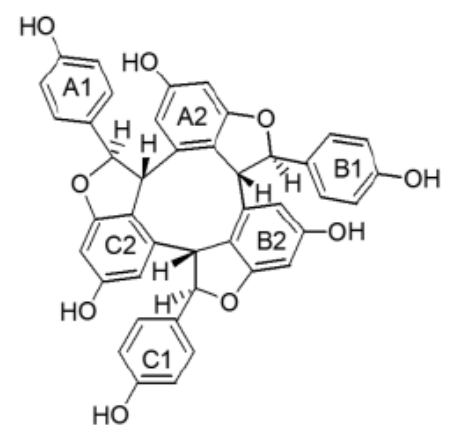

$\alpha$-viniferin

Tabel 1. Data ${ }^{1} \mathrm{H}$ dan ${ }^{13} \mathrm{C}$ NMR (aseton- $d_{6}$ ) senyawa KP-4

\begin{tabular}{|c|c|c|c|c|}
\hline \multirow{2}{*}{ No. C } & \multicolumn{2}{|c|}{$\delta_{\Psi}($ multiplisitas,$J$ dalam $\mathrm{Hz})$} & \multicolumn{2}{|c|}{$\delta$} \\
\hline & KP-4 & $\alpha$-viniferin & $\mathrm{KP}-4$ & $\alpha$-viniferin \\
\hline $1 \mathrm{a}$ & - & - & 132,0 & 132,0 \\
\hline $2 / 6 \mathrm{a}$ & $7,03(d, J=8,8)$ & $7,03(d, J=8,5)$ & 128,2 & 128,1 \\
\hline $3 / 5 \mathrm{a}$ & $6,72(d, J=8,8)$ & $6,72(d, J=8,5)$ & 115,7 & 115,7 \\
\hline $4 \mathrm{a}$ & - & - & 158,2 & 157,8 \\
\hline $7 \mathrm{a}$ & $6,21(b r s)$ & $6,21(b r s)$ & 86,4 & 86,4 \\
\hline $8 a$ & $3,95(b r s)$ & $3,98(b r s)$ & 46,4 & 46,4 \\
\hline $9 a$ & - & - & 141,2 & 141,2 \\
\hline $10 \mathrm{a}$ & - & - & 120,9 & 120,9 \\
\hline $11 \mathrm{a}$ & - & - & 160,6 & 161,6 \\
\hline $12 \mathrm{a}$ & $6,24(d, J=1,8)$ & $6,25(d, J=1,8)$ & 98,0 & 98,0 \\
\hline $13 \mathrm{a}$ & - & - & 159,3 & 159,3 \\
\hline $14 \mathrm{a}$ & $6,72(d, J=1,8)$ & $6,72(d, J=1,8)$ & 106,2 & 106,2 \\
\hline $1 b$ & - & - & 132,5 & 132,5 \\
\hline $2 / 6 b$ & $7,02(d, J=8,4)$ & $7,08(d, J=8,5)$ & 128,7 & 128,6 \\
\hline $3 / 5 b$ & $6,78(d, J=8,4)$ & $6,79(d, J=8,5)$ & 116,1 & 116,1 \\
\hline $4 \mathrm{~b}$ & - & - & 158,4 & 158,3 \\
\hline $7 \mathrm{~b}$ & $4,89(d, J=6,2)$ & $4,90(d, J=6,4)$ & 95,6 & 95,6 \\
\hline $8 \mathrm{~b}$ & $4,60(d, J=6,2)$ & $4,61(d, J=6,4)$ & 55,7 & 55,6 \\
\hline $9 \mathrm{~b}$ & - & - & 141,2 & 141,2 \\
\hline $10 \mathrm{~b}$ & - & - & 118,8 & 118,8 \\
\hline $11 \mathrm{~b}$ & - & - & 161,6 & 161,6 \\
\hline $12 b$ & $6,23(d, J=1,8)$ & $6,22(d, J=1,8)$ & 98,0 & 98,0 \\
\hline $13 b$ & - & - & 159,3 & 159,3 \\
\hline $14 \mathrm{~b}$ & $5,98(d, J=1,8)$ & $5,99(d, J=1,8)$ & 108,6 & 108,5 \\
\hline $1 \mathrm{c}$ & - & - & 132,0 & 132,0 \\
\hline $2 / 6 \mathrm{c}$ & $7,20(d, J=8,4)$ & $7,22(d, J=8,5)$ & 128,1 & 128,1 \\
\hline $3 / 5 c$ & $6,76(d, J=8,4)$ & $6,77(d, J=8,5)$ & 116,1 & 116,2 \\
\hline $4 \mathrm{c}$ & - & - & 157,9 & 157,8 \\
\hline $7 \mathrm{c}$ & $5,93(d, J=9,9)$ & $5,95(d, J=9,7)$ & 90,0 & 90,0 \\
\hline $8 \mathrm{c}$ & $4,68(d, J=9,9)$ & $4,71(d, J=9,7)$ & 52,8 & 52,8 \\
\hline $9 \mathrm{c}$ & - & - & 138,7 & 138,7 \\
\hline $10 \mathrm{c}$ & - & - & 119,7 & 119,7 \\
\hline $11 \mathrm{c}$ & - & - & 161,7 & 161,7 \\
\hline $12 \mathrm{c}$ & $6,20(d, J=1,8)$ & $6,15(d, J=2,0)$ & 96,9 & 96,9 \\
\hline $13 \mathrm{c}$ & - & - & 160,7 & 160,8 \\
\hline $14 \mathrm{c}$ & $6,58(d, J=1,8)$ & $6,46(d, J=2,0)$ & 105,8 & 105,8 \\
\hline
\end{tabular}

*data diambil dari Pryce and Langcake (1977).

Senyawa KP-5, diperoleh sebagai serbuk pergeseran batokromik sebesar $6 \mathrm{~nm}$, yang khas putih kecoklatan, spektrum UV (MeOH) $\lambda_{\text {maks }} 205$, untuk kromofor fenolik sederhana. Spektrum IR 218, 260 dan $290 \mathrm{~nm}$. Penambahan $\mathrm{NaOH}$ terjadi (pellet KBr) senyawa KP-5 memperlihatkan pita- 
pita serapan pada $v_{\text {maks }} 3485 \mathrm{~cm}^{-1}(-\mathrm{OH}), 1679 \mathrm{~cm}^{-1}$ $\left(\mathrm{C}=\mathrm{O}\right.$ karbonil), 1598, 1521, dan $1433 \mathrm{~cm}^{-1}(\mathrm{C}=\mathrm{C}$ benzena), 1299 dan $1207 \mathrm{~cm}^{-1}$ (C-O oksiaril). Pengukuran H-NMR dan C-NMR sedang diproses (di UKM). Berdasarkan data spektrum UV dan IR, senyawa KP-5 mengindikasikan sebagai senyawa flavonoid.

Senyawa KP-6, diperoleh sebagai serbuk putih kecoklatan, spektrum UV (MeOH) $\lambda_{\text {maks }} 203$, 217, 298 dan $325 \mathrm{~nm}$. Penambahan $\mathrm{NaOH}$ terjadi pergeseran batokromik sebesar $49 \mathrm{~nm}$, yang khas untuk kromofor fenolik sederhana. Spektrum IR (pellet $\mathrm{KBr}$ ) senyawa KP-6 memperlihatkan pitapita serapan pada $v_{\text {maks }} 2920$ dan $2850 \mathrm{~cm}^{-1} \quad(\mathrm{C}-\mathrm{H}$ alifatik), $1697 \mathrm{~cm}^{-1}$ ( $\mathrm{C}=\mathrm{O}$ karbonil), 1600, 1515, dan $1461 \mathrm{~cm}^{-1}(\mathrm{C}=\mathrm{C}$ benzena), 1272 dan 1107 $\mathrm{cm}^{-1}$ (C-O oksiaril). Pengukuran H-NMR dan C-NMR sedang diproses (di UKM). Berdasarkan data spektrum UV dan IR, senyawa KP-6 lebih mengindikasikan sebagai senyawa flavonoid.

\section{Hasil uji sitotoksik}

Hasil pengujian sitotoksitas terhadap sel murin leukemia P-388 memperlihatkan harga $\mathrm{IC}_{50}$ masing-masing: senyawa adalah : KP-1 $\left(\mathrm{IC}_{50}\right.$
$=5,1 \mu \mathrm{g} / \mathrm{ml}), \mathbf{K P}-2\left(\mathrm{IC}_{50}=2,25 \mu \mathrm{g} / \mathrm{ml}\right), \quad \mathbf{K P}-\mathbf{3}$ (IC50 tidak terukur), KP-4 $\left(\mathrm{IC}_{50}=71,0 \mu \mathrm{g} / \mathrm{ml}\right)$, KP-5 $\left(\mathrm{IC}_{50}=67,0 \mu \mathrm{g} / \mathrm{ml}\right)$ dan KP-6 (tidak diukur, jumlah sangat sedikit).

Efek sitotoksik terhadap sel uji tumor (malignant cell lines) secara in vitro menurut Alley (1988) dikategorikan sangat aktif $(++)$ untuk nilai $\mathrm{IC}_{50}<2 \mu \mathrm{g} / \mathrm{ml}$, aktif (+) $2-4 \mu \mathrm{g} / \mathrm{ml}$, dan tidak aktif bila $\mathrm{IC}_{50}>4 \mu \mathrm{g} / \mathrm{ml}$. Kategori berdasarkan satuan $\mu \mathrm{g} / \mathrm{ml}$ memiliki kelemahan karena tidak memperhatikan ukuran (berat) molekul. Sedangkan menurut Ito et al. (2003), berdasarkan hasil kajian sitotoksik terhadap beberapa sel uji kanker dari senyawa-senyawa oligomer resveratrol, dinyatakan bahwa senyawa dikatakan sangat aktif $(++)$ bila memiliki nilai $\mathrm{IC}_{50}$ $<10 \mu \mathrm{M}$, aktif $(+) 10-20 \mu \mathrm{M}$, dan tidak aktif jika nilai $\mathrm{IC}_{50}>20 \mu \mathrm{M}$.

Hasil pengujian efek sitotoksik senyawasenyawa hasil isolasi terhadap sel murin leukemia P388 [ex. HSRRB Lot Number: 113098 seed (JCRB0017)] yang dilakukan di Laboratorium Kimia Organik Bahan Alam, Departemen Kimia Institut Teknologi Bandung sebagai berikut:

Tabel 2. Hasil pengujian efek sitotoksik senyawa-senyawa hasil isolasi terhadap sel murin leukemia P388

\begin{tabular}{ccccc}
\hline NO. & SENYAWA & $\mathbf{I C}_{\mathbf{5 0}}(\boldsymbol{\mu g} / \mathbf{m l})$ & KET.* & KET.** \\
\hline KP-1 & 5,1 & Tidak aktif & Sangat aktif \\
KP-2 & 2,25 & Aktif & Sangat aktif \\
KP-3 & t.t & Tidak larut DMSO & Tidak larut DMSO \\
KP-4 & 71,0 & Tidak aktif & Tidak aktif \\
KP-5 & 67,0 & Tidak aktif & Tidak aktif \\
KP-6 & t.t & Tidak diukur & Tidak diukur \\
\hline
\end{tabular}

*Berdasarkan pengkategorian oleh Alley (1998).

** Berdasarkan pengkategorian oleh Ito et al. (2003).

Senyawa KP-1 dan KP-2 memiliki aktivitas sitotoksik yang lebih kuat dibandingkan senyawa KP-4 dan KP-5. Senyawa KP-3 tidak terukur (t.t), karena tidak dapat larut dalam DMSO, sedangkan KP-6 karena jumlahnya sangat sedikit $(5 \mathrm{mg}$ ) dan berdasarkan spektrum IR-nya, masih mengindikasikan adanya pengotor yang cukup signifikan, maka tidak dilakukan pengujian efek sitotoksiknya.

Senyawa KP-2, yang mengindikasikan sebagai senyawa flavonoid menunjukkan aktivitas sitotoksik yang paling kuat terhadap sel murin leukemia P388. Padahal berdasarkan laporan penelitian terdahulu, senyawa flavonoid yang diisolasi dari ekstrak kulit kayu Dipterocarpus (keruing), tidak memiliki efek sitotoksik terhadap sel murin leukemia P388. Dilaporkan, senyawa 4'-O-metilgalokatecin yang telah diisolasi dari $D$. elongatus memiliki efek sitotoksik yang sangat lemah (tidak aktif) dengan nilai $\mathrm{IC}_{50}$ sebesar $70 \mu \mathrm{g} / \mathrm{mL}$ (Muhtadi, 2007). Sedangkan senyawa-senyawa yang memiliki efek sitotoksik sangat kuat (aktif) dari ekstrak tumbuhan famili Dipterocarpaceae adalah hopeafenol $\left(\mathrm{IC}_{50}\right.$ 5,5 $\mu \mathrm{M})$ dan diptoindonesin $\mathrm{G}\left(\mathrm{IC}_{50} 4,4 \mu \mathrm{M}\right)$. Akan tetapi, berdasarkan data spektrum UV dan IRnya, senyawa KP-2 tidak memiliki kemiripan sifat-sifat dengan senyawa hopeafenol maupun diptoindonesin G (Sahidin, 2006). 
<smiles>O=C1c2cc(O)cc(O)c2C(c2ccc(O)cc2)Cc2cc(O)cc(O)c21</smiles>

Diptoindonesin $\mathrm{G}\left(\mathrm{IC}_{50} 4,4 \mu \mathrm{M}\right)$

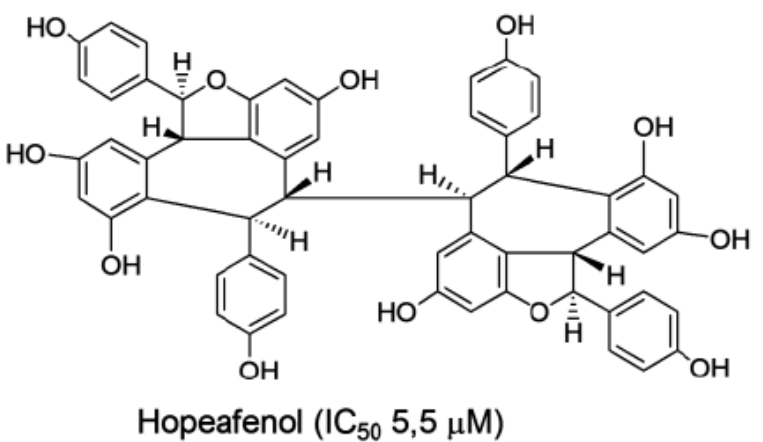

Oleh karena itu, penelitian lanjutan untuk menentukan struktur kimia senyawa KP-2 yang memiliki efek sitotoksik yang sangat kuat tersebut, dan melakukan uji farmakologi molekuler untuk mengetahui mekanisme penghambatan terhadap sel kanker sangat penting untuk dilakukan.

Pengujian efek toksisitas; akut dan subkronis juga penting untuk dilakukan, agar diperoleh data ilmiah yang kuat tentang potensi pemanfaatan ekstrak, isolat atau senyawa KP-2 sebagai antikanker. Hasil kajian farmakologi (khasiat) dan toksisitas (efek samping) ini, akan memberikan landasan ilmiah yang kuat tentang seberapa besar potensi pemanfaatan ekstrak atau isolat dari kulit kayu keruing Pungguh (D. confertus Sloot) sebagai agen fitofarmaka antikanker.

\section{SIMPULAN}

Enam senyawa telah berhasil diisolasi dari ekstrak metanol kulit batang D. confertus Sloot, dua diantaranya (KP-2 dan KP-1) sangat aktif dalam pengujian efek sitotoksiknya terhadap sel murin leukemia $\mathrm{P} 388$, dengan nilai $\mathrm{IC}_{50}$ masing-masing sebesar 2,25 dan $5,1 \quad 7,8 \mu \mathrm{g} / \mathrm{ml}$. Berdasarkan analisis spektroskopi yang telah ada, KP-2 mengindikasikan sebagai senyawa flavonoid, sedangkan KP-1 mengindikasikan sebagai triterpenoid.

\section{Persantunan}

Kami ucapkan terima kasih kepada Direktorat DP2M Dikti Depdiknas atas biaya Penelitian Hibah Bersaing Tahun Anggaran 2008, Bapak Dr. Edi K. dari Universitas Tanjungpura Pontianak atas bantuannya dalam menyediakan sampel tumbuhan, serta staf Herbarium Bogoriensis Bogor dalam determinasi tumbuhan.

\section{DAFTAR PUSTAKA}

Alley, M.C., Scudiero, D.A., Monks, A., Hursey, M.L., Czerwinski, M.J., Fine, D.L., Abbott, B.J., Mayo, J.G., Shoemaker, R.H., Boyd, M.R. (1988) : Feasibility of Drug Screening with Panels of Human Tumor Cells Lines Using a Microculture Tetrazolilum Assay, Cancer Res., 48, 589-601.

Bokel, M., M.N.C. Diyasena, A.A.L. Gunatilaka, W. Kraus, S. Sotheeswaran (1988), Caliculatol, an antifungal resveratrol trimer from Stemonoporus canaliculatus, Phytochemistry, 27, 377-380

Cronquist, A. (1981), An intergrated system of classification of flowering plant, Columbia University Press, New York, 317-318

Dai, J.R., Y.F. Hallock, J.H. Cardellina II, M.R., Boyd (1998), HIV-Inhibitory and cytotoxic oligostilbenes from the leaves of Hopea malibato, J. Nat. Prod., 61, 351-353

Geewananda, Y.A., P. Gunawardena, S. Sotheeswaran, M.U.S. Sultanbawa, S. Surendrakumar, P. Bladon (1986), Another antibacterial polyphenol, coppaliferol B, from Vaterian copallifera (Dipterocarpaceae), Phytochemistry, 25, 1498-1500

Hakim, E.H. (2002), Oligostilbenoid dari tumbuhtumbuhan Dipterocarpaceae, Bull. Soc. Nat. Prod. Chem., 2, 1-9

Hegnauer, R. (1966), Chemotaxonomie der pflanzen, Band 4, Birkhauser Verlag Basel und Stuttgart, 31-40

Heyne, K. (1987), Tumbuhan berguna Indonesia, Vol II, Balai Kehutanan Indonesia, Departemen Kehutanan, Jakarta, 1420

Hirano, Y., R. Kondo, K. Sakai (2001), Compounds inhibitory to rat liver $5 \alpha$-reductase from tropical commercial wood species: resveratrol trimers from melapi (Shorea $s p$.) heartwood, J. Wood. Sci., 47, 308-312 
Hostettmann, K. (1991) : Assays for Bioactivity. Method in Plant Biochemistry, Series Editor P.M. Dey and J.B. Harborne, Vol. 6, Academic Press, London.

Huang, K., Y. Wang, R. Li, M. Lin (2000), Five new stilbene dimers from the lianas of Gnetum hainanse, J. Nat. Prod., 63, 86-89

Ito, T., Akao, Y., Yi, H., Ohguchi, K., Matsumoto, K, Tanaka, T., Iinuma, M., Nozawa, Y. (2003) : Antitumor Effect of Resveratrol Oligomers Against Human Cancer Cell Lines and The Molecular Mechanism of Apoptosis Induced by Vaticanol C, Carcinogenesis, 24(9), 1489-1497.

Ito, T., T. Tanaka, K. Nakaya, M. Iinuma, Y. Takashashi, H. Naganawa, M. Ohyama, Y. Nakanishi, K.F. Bastow, K. Lee (2001-a) : A Novel Bridged Stilbenoid Trimer and Four Highly Condensed Stilbenoid Oligomers in Vatica rassak, Tetrahedron, 53, 7309-7314.

Ito, T., T. Tanaka, K. Nakaya, M. Iinuma, Y. Takashashi, H. Naganawa, M. Ohyama, Y. Nakanishi, K.F. Bastow, K. Lee (2001-b), A new resveratrol octamer, vateriaphenol A, in Vateria indica, Tetrahedron letters, 42 , 5909-5912

Ito, T., T. Tanaka, M. Iinuma, K. Nakaya, Y. Takashashi, R. Sawa, J. Murata, D. Darnaedi, (2004), Two new resveratrol (=5-[(1E)-2-(4hydroxyphenyl)ethenyl]-benzene-1,3-diol) tetramer with a tetrahydrofuran ring from Dipterocarpus grandiflorus, Helvetica Chimica Acta. 87, 479-495

Kitanaka, S., M. Takido, K. Mizoue, H. Kondo, S. Nakaike (1996), Oligomeric stilbenes from Caragana chamlagu Lamark root, Chem. Pharm. Bull., 44, 565-567

Muhtadi (2007), Fitokimia Beberapa Spesies Dipterocarpaceae Indonesia dari Genus Dipterocarpus (Keruing), Disertasi, Dep. Kimia, Program Pasca Sarjana ITB, Bandung

Muhtadi, Hakim, E.H., Syah, Y.M., Juliawaty, L.D., Achmad, S.A., Said, I.M., Din, L.B. dan Latip, J. (2006-a) : Resveratrol Tetramers from Dipterocarpus intricatus and Cytotoxic Activity against Murine Leukemia P-388 Cells, Collective Abstracts of the International Conference on Mathematics and Natural Sciences (ICMNS), ITBBandung, 29-30 November 2006.

Muhtadi, Hakim, E.H., Syah, Y.M., Juliawaty, L.D., Achmad, S.A. dan Latip, J. (2006-b) : Pemisahan dan Karakterisasi Senyawa Oligostilbenoid dari Kulit Batang Dipterocarpus hasseltii (Dipterocarpaceae), Alchemy, Vol. 5 (1), Maret 2006, 8-15.
Muhtadi, Hakim, E.H., Syah, Y.M., Juliawaty, L.D., Achmad, S.A. Latip, J., Ghisalberti, E.L. (2006-d) : Cytotoxic Resveratrol Oligomers from the Tree Bark of Dipterocarpus hasseltii,Journal of Fitoterapia, Vol. 77, Issues 7-8, December 2006, 550-555.

Muhtadi, Hakim, E.H., Juliawaty, L.D., Din, L.B. dan Latip, J. (2006-c) : Lima Senyawa Oligostilbenoid dari Kulit Batang Dipterocarpus hasseltii dan Aktivitas Sitotoksiknya terhadap Sel Murin Leukemia P-388, Bulletin of the Indonesian Society of Natural Products Chemistry, Vol. 6 (1), January-June 2006, 19-26.

Muhtadi, Hakim, E.H., Syah, Y.M., Juliawaty, L.D., Makmur, L., Achmad, S.A., Din, L.B. dan Latip, J. (2005) : Tiga Senyawa Oligostilbenoid dari Kulit Batang Dipterocarpus retusus Blume (Dipterocarpaceae), Jurnal Matematika \& Sains, Vol. 10 (4), Desember 2005, 135-141.

Newman, M.F., P.F. Burges, T.C. Whitemore (1999), Pedoman identifikasi Pohon Dipterocarpaceae Pulau Kalimantan, Prosea Indonesia, Bogor

Oshima, Y., Y. Ueno, K. Hisamichi, M. Takeshita (1993), Ampelopsin F and G, Novel bridged plant oligostilbenes from Ampelopsis brevipedunculata var. hancei roots (Vitaceae), Tetrahedron, 49, 5801-5804

Pryce, R.J., P. Langcake (1977), $\alpha$-Viniferin: an antifungal resveratrol trimer from grapevines, Phytochemistry, 16, 1452-1454

Sahidin (2006) : Keanekaragaman Senyawa Oligomer Resveratrol dari Tumbuhan Hopea dan Tumbuhan Sejenis dari Famili Dipterocarpaceae Indonesia, Disertasi Program Doktor, Institut Teknologi Bandung, 131-133.

Soerianegara, I., R.H.M.J. Lemmens (1994), Timber trees: Major commercial timbers, PROSEA, Bogor Indonesia

Sotheeswaran, S., M.N.C. Diyasena, A.A.L. Gunatilaka, M. Bokel, W. Kraus (1987), Further evidence for the structure of vaticaffinol and a revision of its stereochemistry, Phytochemistry, 26, 1505-1507

Sotheeswaran, S., M.U.S. Sultanbawa, S. Surendrakumar, P. Bladon (1983), Polyphenol from Dipterocarp species copalliferol A and stemonoporol, $J$. Chem. Soc., Perkin Trans. 1, 4, 699-702 
Sotheeswaran, S., V. Pasupati (1993), Distribution of resveratrol oligomers in plants, Phytochemistry, 32,1083-1092

Sukhla, R.N., Sharma, S.P., Srivastava, R.M. (1990) : On Chemical Composition of Shorea robusta, Vijnana Parishad Anusandhan Patrika, 33(4), 253-261.

Sung, S.H., S.Y. Kang, K.Y. Lee, M.J. Park, J.H. Kim, J.H. Park, Y. Choong Kim, J. Kim, Y.C. Kim, J. Kim, Y.C. Kim (2002), (+)- $\alpha$-Viniferin, a stilbene trimer from Caragana chamlague, inhibits acetylcholinesterase, Biol. Pharm. Bull., $25,125-127$
Tanaka, T., T. Ito, K. Nakaya, M. Iinuma, Y. Takashashi, H. Naganawa, N. Matsuura, M. Ubukata (2000-b), Vaticanol D, a novel resveratrol hexamer isolated from Vatica rassak, Tetrahedron Letters, 41, 7929-7932

Zgoda-Pols, J.R., A.J. Freyer, L.B. Killmer, and J.R. Porter (2002), Antimicrobial resveratrol tetramers from the stem bark of Vatica oblongifolia, J. Nat. Prod, 65, 1554-1559 